\title{
The Role of Banks in Dividend Policy
}

\author{
Linda Allen \\ Zicklin School of Business, Baruch College, CUNY \\ Aron Gottesman \\ Lubin School of Business, Pace University \\ Anthony Saunders \\ Stern School of Business, New York University \\ Yi Tang \\ Fordham University Graduate School of Business Administration \\ August 2009

\begin{abstract}
$\underline{\text { Abstract }}$
We document a significant inverse relationship between a firm's dividend payouts and reliance on bank loan financing. Banks limit dividend payouts to shareholders in order to protect the integrity of their senior claims on the firm's assets. Moreover, dividend payouts decline in the presence of monitoring by relationship banks, which acts as an effective governance mechanism, thereby reducing the gains from pre-committing to costly dividend payouts. Bank monitoring and corporate governance (insider stake and institutional block holdings) are complementary mechanisms to resolve firm agency problems, both reducing the firm's reliance on dividend policy.
\end{abstract}




\title{
The Role of Banks in Dividend Policy
}

\begin{abstract}
$\underline{\text { Abstract }}$
We document a significant inverse relationship between a firm's dividend payouts and reliance on bank loan financing. Banks limit dividend payouts to shareholders in order to protect the integrity of their senior claims on the firm's assets. Moreover, dividend payouts decline in the presence of monitoring by relationship banks, which acts as an effective governance mechanism, thereby reducing the gains from pre-committing to costly dividend payouts. Bank monitoring and corporate governance (insider stake and institutional block holdings) are complementary mechanisms to resolve firm agency problems, both reducing the firm's reliance on dividend policy.
\end{abstract}

JEL Classification: G30, G34, G35

Key Words: Dividend, Bank lending intensity, monitoring, corporate governance 


\section{The Role of Banks in Dividend Policy}

Dividends have long been viewed as an effective, but costly, mechanism to align the incentives of managers and stockholders (see, for example, Jensen and Meckling (1976), Rozeff (1982) and Jensen (1986)). ${ }^{1}$ Managers pre-commit to an inflexible dividend payout policy so as to limit their access to free cash flows that could be diverted for managerial private benefits, empire building or other inefficient investment policies that do not maximize firm value. Thus, dividends can be viewed as a corporate governance mechanism. John and Knyazeva (2006) show that weakly governed managers are under more pressure from stockholders to pay dividends, and are subject to greater penalties (in terms of adverse shareholder reaction) if they reduce dividend payouts. Guay and Harford (2000) find that managers use dividend payouts to distribute cash flows that are viewed to be relatively permanent. Moreover, Knyazeva (2007) finds that weakly governed managers are more likely to engage in dividend smoothing so as to obviate the need for costly dividend reductions in the event that cash flows fall. Thus, an important component of the oversight aspect of dividend policy is its inflexibility, which imposes costs on firms that constrain pre-committed firms from investing internally generated funds in negative net present value investments (see Easterbrook (1984)).

The literature on the corporate governance role of dividend policy has focused on the incentive conflict between managers and equity holders. However, this focus does not consider the incentive conflict between lenders and managers/shareholders. ${ }^{2}$ This paper addresses this issue. For instance, lenders such as relationship banks might block dividend payouts to stockholders, since they reduce the firm's cash resources available to service the firm's debt obligations. In particular, bank loans regularly include covenants that limit dividend payouts. ${ }^{3}$ Moreover, banks act as delegated monitors in their role as relationship lenders. Thus, the

\footnotetext{
${ }^{1}$ Dividends have also been considered to be a signaling mechanism (as in Miller and Rock (1985)). However, the ability of dividends to signal unexpected future changes in firm earnings has been questioned in Benartzi et al. (1997, 2005). Lie and McConnell (1998) find that repurchase agreements have little ability to forecast future performance. Moreover, Liu, Szewczyk and Zantout (2008) find that there is no long-term abnormal performance impact of dividend reductions or omissions.

${ }^{2}$ Knyazeva (2007) shows that debt and dividends are substitute corporate governance mechanisms, but does not analyze the monitoring role of bank lending. Aivazian, Booth and Cleary (2006) contrast the relationship between dividend smoothing policy and publicly debt holdings versus bank debt and find that firms with public debt are more likely to pay dividends than firms with private debt.

${ }^{3}$ Allen and Gottesman (2006) show that the majority of the syndicated bank loans in their sample contain covenants restricting dividend payout.
} 
potential corporate governance benefits associated with dividend payouts is of limited value in the presence of active bank monitoring of managerial activities. In this paper, we consider the impact of bank lending on dividend policy. We hypothesize that dividend payouts should decline in the presence of substantial bank lending for two complementary reasons: (1) monitoring by relationship banks acts as an effective governance mechanism, thereby reducing the gains from pre-committing to costly dividend payouts (the corporate governance motivation) and (2) banks limit dividend payouts to shareholders in order to protect the integrity of their senior claim on the firm's assets (the cash flow protection motivation).

Management can return cash to equity holders through stock repurchases as well as via dividend payouts. However, stock repurchases are less effective as a corporate governance mechanism than dividend payouts precisely because they are episodic, non-binding and flexible. ${ }^{4}$ For example, Guay and Harford (2000) show that repurchases are used to redistribute transient cash flow shocks. Knyazeva (2007) shows that poorly governed managers utilize declines in repurchases to adjust for cash flow declines, but pay higher dividends when cash flows increase because declines in share repurchase programs have less of an adverse effect on stock prices than dividend cuts. Since the corporate governance motivations associated with stock repurchases are less clear cut, we focus on dividend policy in this paper.

While there is a well-established literature on resolving the bondholder-stockholder agency conflict (for example, see the Barnea, Haugen and Senbet (1981) survey paper), the bank-stockholder conflict is different for a number of reasons. First, banks have potential access to inside information regarding a firm's performance, whereas bondholders generally do not. Second, banks develop relationships with borrowers which create costs of borrower switching, whereas bondholders are usually transactional purchasers. Third, even if a bank loan is syndicated, the number of banks in a syndicate tends to be far smaller than the number of bondholders in a public bond offering. Thus, because of their monitoring ability and large debt stake in borrowing firms, banks may exercise considerable control over dividend policy.

Bank lending intensity (i.e., firm reliance on bank loan financing) can impact dividends via both the corporate governance and the cash flow protection motivations. The more intensive the banking relationship, the greater the amount of private information produced in the course of

\footnotetext{
${ }^{4}$ Hausch and Seward (1993) and Jagnnathan et al. (2000) show that firms do not have to comply with announced terms of stock repurchase programs. Stephens and Weisbach (1998) document that approximately $80 \%$ of announced share repurchases are completed.
} 
the lending relationship and the more extensive the bank monitoring activity, thereby obviating the need for corporate governance through pre-commitment of dividend payouts. Moreover, the higher the bank lending intensity, the more power the bank has to impose its cash flow protection preferences on the firm, thereby lowering dividend payouts. Thus, we hypothesize that firms more dependent on bank loan financing will have lower dividend payouts, ceteris paribus. We utilize two independent methodologies to comprehensively examine the relationship between dividend payout and bank lending intensity. First, we control for the endogeneity in the firm's dividend policy using a two-stage instrumental variable (IV) approach. Second, we utilize a matched-pair sampling technique to control for both bank lending intensity and corporate governance variables.

We find that firms with greater reliance on bank loan financing have significantly lower dividend payouts. For example, a one standard deviation increase in bank loan intensity suggests a 5.78\% decline in dividend payouts at all firms, even after controlling for corporate governance controls such as insider stake and institutional block holdings. Thus, bank loan monitoring complements other corporate governance mechanisms in addressing potential agency conflicts, obviating the need for costly dividend pre-commitment.

The paper proceeds as follows. Section 2 describes the database and provides descriptive statistics. The regression analysis and the matched sample results are discussed in Sections 3 and 4 , respectively. The paper concludes in Section 5.

\section{Data}

\subsection{Sample Selection and Variable Description}

We hypothesize that bank lending should impact firm dividend policy. To empirically test how bank lending intensity relates to firm dividends, we obtain loan, accounting, and stock return data for each fiscal year spanning the period 1990 through $2006 .{ }^{5}$ Information on bank loans is collected from the DealScan database of the Loan Pricing Corporation (LPC). The accounting data are obtained from the Compustat Annual Industrial files and stock prices are extracted from the CRSP database.

For each firm, we estimate the intensity of bank lending (LOAN_INTENSITY), defined as total amount of outstanding loans provided by banks to the firm during the previous three fiscal

\footnotetext{
${ }^{5}$ The sample period begins in 1990 because one of our variables, loan intensity, requires three years of data, and this data is only available on Loan Pricing Corporation's DealScan database from 1987.
} 
years $(t-1, t-2$, and $t-3)$ normalized by the book value of total assets of the firm at the beginning of the given fiscal year $t$. Loans that mature before the end of fiscal year $t$ are excluded. For term loans, we carry out a linear interpolation to estimate the remaining balance of the loan. ${ }^{6}$ The loan intensity measure can overstate the amount of bank loans outstanding due to refinancing deals and/or revolving lines of credit since the DealScan database does not differentiate between new loans and refinancing deals. ${ }^{7}$ In addition, many of the loan agreements contain revolving credit lines for which no data is provided regarding the fraction utilized. We therefore assume $50 \%$ utilization of credit lines.

We define two additional loan related variables to be used as instrumental variables: IND_LOAN_INTENSITY, defined as average LOAN_INTENSITY for each of 10 industry classifications, ${ }^{8}$ and $N O \_L E A D$, defined as the number of lead arrangers (value-weighted) for all of the loans originated between year $t-3$ and $t-1$ with maturity after year $\mathrm{t}$ for each borrower. The role of these variables will be described in Section 3.2.

We use two variables to proxy for firm dividend policy. DIV denotes the ratio of cash dividends to the book value of total assets, which has a lower bound value of zero. However, to distinguish between dividend-paying and non-dividend paying firms, we construct a dummy variable entitled DIVABOVEZERODUMMY equal to one if DIV is greater than zero and zero otherwise.

We proxy for agency conflicts using Jensen's free cash flow variable, $F C F$, measured as EBITDA minus changes in working capital (current assets minus current liabilities) minus capital expenditure. Capital expenditure is set to zero if missing. Our sample consists of US firms with publicly traded equity. COVENANT is a dummy variable that is equal to 1 if a loan deal contains a covenant restricting dividend payouts, as reported on the DealScan database. PROB_KMV is the implied probability of default, a measure of default risk, estimated using a Merton optionstheoretic model. ${ }^{9}$

\footnotetext{
${ }^{6}$ Term loans include "Term Loan", "Delay Draw Term Loan”, “Term Loan A," “Term Loan B," through "Term Loan H."

7 Revolving loans include "Revolver/Line<1 Yr.", "Revolver/Line>1 Yr.", "Revolver/Term Loan", “364-day Facility", "Demand Loan" and "Limited Line."

8 These industry classifications are specified by Professor Kenneth French. See his website: http://mba.tuck.dartmouth.edu/pages/faculty/ken.french/data library.html.

${ }^{9}$ Appendix 1 describes the method used to estimate $P R O B_{-} K M V$. This measure is a time-consistent indicator of variations in the likelihood of default, but is distinct from the true probability of default due to the assumption that asset market values are normally distributed. The estimation of the true probability of default would require
} 
Ever since the Modigliani Miller irrelevance theorem, economists have puzzled over why firms that issue debt in order to raise capital for investment purposes simultaneously pay out cash flows to shareholders in the form of dividends and stock repurchases. We, therefore, control for LEVERAGE, measured as the book value of current and long-term debts. In order to control for potential agency conflicts, we define $D E B T+D U M$ is a dummy variable that is equal to 1 if the firm does not have an outstanding (i.e., maturity date after the end of fiscal year $t$ ) debt instrument with an S\&P credit rating.

We also control for $L D I V$, the lag of DIV, LNASSET, defined as the natural logarithm of the book value of the firm's total assets, and INCOME, defined as the firm's net income, and the market to book asset ratio, $M B$, measured as the ratio of the market value of equity plus the book value of current and long-term debts to the book value of total assets. Moreover, following Rozeff (1982) we use risk levels, measured by the control variable RISK, which is defined as the standard deviation of market-adjusted monthly stock returns in the given year $t$. We control for taxes using the variable TAXES, defined as total income tax normalized by EBIT, growth using the variable GROWTH, defined as the relative changes in net sales from the previous fiscal year. We use INTANGIBLE, defined as the ratio of intangible assets to total assets, to control for investment opportunities as well as information asymmetry about the firm. We include dummy variables for fiscal year and for ten industry classifications, as defined by Kenneth French.

We start with 73,342 observations for "completed" or "closed" loan facilities originated by 21,901 borrowers between 1983 and 2006 on the DealScan database. This sample is merged with Compustat using a matching algorithm comparing the borrower's name, as provided by LPC, with the firm's name as shown in Compustat. ${ }^{10}$ We are able to identify 7,218 borrowers on the Compustat database, which correspond to 36,236 loan facilities. We obtain 20,592 loan intensity observations following the aforementioned variable definition. We eliminate 4,619 observations for which dividend or control variables are unavailable. We further eliminate 736 financial and utilities observations (SIC codes 6000-6999 and 4900-4949). The resulting sample contains 15,237 observations spanning the period of fiscal year 1990 to 2006. All variables are estimated on an annual basis. To avoid giving extreme observations heavy weight in the analysis,

calibration against a large sample of defaults, such as the proprietary database used by Moody's/KMV. Please see Chapter 4 of Saunders and Allen (2002) for a discussion.

${ }^{10}$ Company names and ticker symbols are the only identifiers commonly shared by the DealScan database and the Compustat database. Given that ticker symbols change more frequently than company names, we link the DealScan observations to the Compustat database through the company name. 
we winsorize all the variables in the sample at the 0.005 and 0.995 fractiles except for the dummy variables.

In order to measure the extent of corporate governance mechanisms, we obtain institutional holdings from Thomson Financial 13f filings. The institutional holding variable, INSTHLD, is constructed by averaging quarterly institutional ownership data for each firm-year. Following Cremers and Nair (2005), INSTHLD is set to 0 if missing. We extract insider holdings from Thomson Insider filings. The insider holding variable, INSIDER, is the total market value of shares held by firm's management at the end of fiscal year $t$ normalized by the firm's market capitalization. We also utilize the INSIDER^2 variable (squared INSIDER) to control for nonlinearity in the corporate governance role of managerial shareholdings. That is, Stulz (1988) and Morck, Shleifer and Vishny (1988), McConnell and Servaes (1990) and Wruck (1989) provide evidence that managerial stockholdings align the interests of managers and shareholders only up to a point, after which entrenched managers utilize their control power to obtain private gains at the expense of stockholders and other stakeholders.

Table 1 provides descriptive statistics of our sample, and Table 2 provides correlations. The mean loan intensity in our sample is $18.09 \%$, ranging from a minimum of $1.38 \%$ to a maximum of $72.78 \%$. The dividend payout ratio for the firms in our sample average $0.67 \%$, ranging from zero to a maximum of $9.27 \%$. As evidence of the connection between bank loans and payout policy, Table 1 shows that more than $50 \%$ of the loans in our sample have dividend restricting covenants. Indeed, Table 2 shows that the correlation between dividend payout and the existence of a dividend restricting covenant is -0.16 .

The persistence of dividend payouts over time is shown in Table 2 by the 0.58 correlation coefficient between $D I V$ and lagged dividends, $L D I V$. Table 3 provides a univariate analysis of the relation between $L O A N \_I N T E N S I T Y$ and dividend payout policy. Observations are ranked on the basis of LOAN_INTENSITY and placed into one of 20 groupings on this basis. The mean values of DIV and DIVABOVEZERO are reported for each grouping. Table 3 shows that the dividend payout tends to decrease as bank loan intensity increases. For example, the smallest group has an average loan intensity of $1.98 \%$ and a dividend payout averaging $0.89 \%$ overall and $49.15 \%$ for dividend paying firms only. In contrast, the highest loan intensity group has an average bank loan intensity of $60.37 \%$ and an average dividend payout of $0.33 \%$ overall and $28.78 \%$ for dividend paying firms only. To test this preliminary evidence of an inverse 
relationship between bank loan intensity and dividend payout policy, the next section presents the results of our two-stage IV regression analysis.

\section{INSERT TABLES 1, 2, AND 3 AROUND HERE}

\section{Regression Analysis}

To test the relation between dividends and loan intensity we estimate the following model:

DIVIDEND MEASURE $=\alpha+\gamma \cdot \ln ($ LOAN_INTENSITY $)+\beta^{\prime} \cdot \operatorname{CONTROLS}+e$

We use three different specifications for the dividend measure: $D I V, \ln (D I V)$, and DIVABOVEZERODUMMY. All observations in the sample are used when either DIV or DIVABOVEZERODUMMY is the dependent variable, while only observations where $D I V$ is greater than zero are used when $\ln (D I V)$ is the dependent variable. Hence, when $D I V$ is the dependent variable, we are testing the overall relation between dividend level loan intensity. When DIVABOVEZERODUMMY is the dependent, we are testing whether there is a relationship between the loan intensity and the decision to issue dividends. When $\ln (D I V)$ is the dependent, we are testing whether firms base their dividend payout level on loan intensity, conditional on the decision to pay dividends.

The vector of control variables, defined as follows:

CONTROLS $=[L D I V, C O V E N A N T$, GROWTH, LNASSETS, INCOME, LEVERAGE, FCF, MB, TAXES, RISK, INTANGIBLE, PROB_KMV,DEBT_DUM, INSIDER, INSIDER^2, INSTHLD, industry dummies, fiscal year dummies]

Where $L D I V=$ lagged dividend payout, $C O V E N A N T=$ dummy variable indicating loan covenant restricting dividends, GROWTH=annual change in net sales, LNASSETS=natural logarithm of the book value of the firm's total assets, $I N C O M E=$ net income, $L E V E R A G E=, F C F=$ free cash flow, $M B=$ the ratio of the market value of equity plus the book value of current and long-term debts to the book value of total assets, TAXES=total income tax normalized by EBIT, $R I S K=$ standard deviation of annualized market-adjusted monthly stock returns, $I N T A N G I B L E=$ the ratio of intangible assets to total assets, $P R O B \_K M V=$ the annualized probability of default, $D E B T_{-} D U M=$ dummy variable indicating the absence of a rated debt 
instrument, INSIDER=managerial stockholdings normalized by market capitalization, $I N S I D E R^{\wedge} 2=I N S I D E R^{2}, I N S T H L D=$ quarterly institutional stock ownership.

We perform two types of regression tests. We initially implement ordinary regression models, under the assumption that LOAN_INTENSITY is exogenous. We then implement an instrumental variable (IV) methodology to control for the possibility that LOAN_INTENSITY is endogenous.

\subsection{Simple Regression Estimation}

The results of the estimation of equation (1) are reported in Table 4. As a first pass, we implement ordinary least squares (OLS) regression models, assuming (counterfactually) that LOAN_INTENSITY is exogenous to the dividend payout decision. Since DIV is left censored with a lower bound of zero, we implement a Tobit estimation technique when $D I V$ is the dependent variable (results presented in column (1) of Table 4). Since DIVABOVEZERODUMMY is a dummy variable, we estimate the model with DIVABOVEZERODUMMY as the dependent using a Probit model (results in column (2) of Table 4). When $\ln (D I V)$ is the dependent variable, we implement OLS (results in column (3) of Table 4). In all specifications, standard errors are adjusted for the possibility of heteroskedasticity and firm clustering. ${ }^{11}$

The bank loan intensity coefficients in all three regressions are negative and statistically significant at the 5\% level or better, indicating an inverse relationship between dividend payout and firm dependence on bank loans. All other coefficients have the expected signs. For example, there is a statistically significant negative relationship between dividend payout (however defined) and firm growth, dividend restricting loan covenants, default risk, total risk, leverage and publicly traded debt. In contrast, dividend payout is positively related to asset size, firm profitability (income) and free cash flow. Moreover, the corporate governance variables controls show that dividend payout decreases when there are large institutional block holders that monitor management's activities (negative coefficient on INSTHLD). Dividend payout decreases when managerial stake is higher thereby aligning managerial incentives to stockholders' interests (negative coefficient on INSIDER), but at a decreasing rate indicating the increase in dividend pre-commitment to limit private control benefits as managerial entrenchment increases (positive coefficient on $I N S I D E R^{\wedge} 2$ ).

\footnotetext{
${ }^{11}$ The results are robust to unadjusted standard errors.
} 


\section{INSERT TABLE 4 AROUND HERE}

\subsection{Two-Stage Instrumental Variables Regression Analysis}

While suggestive, the simple linear regression presented in Table 4 does not take into account the likely possibility that LOAN_INTENSITY is endogenous, which can result in biased estimates. That is, firms that have a low dividend payout policy (for whatever reason) may choose to borrow less from banks. In order to test whether the simple models presented in Table 4 are subject to selectivity bias and endogeneity, we perform formal tests for the endogeneity of LOAN_INTENSITY, including the Durbin-Wu-Hausman test (Davidson and MacKinnon, 1993, Durbin, 1954, Hausman, 1978 and Wu, 1973) for the OLS regression model and the test for endogeneity proposed by Smith and Blundell (1986) for the Probit and Tobit models. Panel A of Table 5 reports the results of these tests. These tests all reject the null hypothesis of exogeneity. Therefore, we must control for the endogeneity in the level of bank loan intensity.

To control for the endogenity of LOAN_INTENSITY we implement the method of instrumental variables, whereby the endogenous regressor, LOAN_INTENSITY, is instrumented against the controls in equation (2). The dividend measure is regressed on the predicted values of LOAN_INTENSITY as well as the control variables. Maximum likelihood estimation is used when the structural equation is Probit or Tobit. Two-stage least squares is used when the structural equation is ordinary least squares. Standard errors are adjusted for the possibility of heteroskedasticity and firm clustering. ${ }^{12}$

The instruments we use are the industry bank loan intensity IND_LOAN_INTENSITY and the number of lead arrangers $N O_{-} L E A D$ variables. The IV method requires the identification of instruments that are correlated with the endogenous regressor, but not with the structural equation's error term. Hence, the instruments must be correlated with LOAN_INTENSITY and must only influence the dividend measures through LOAN_INTENSITY. Consistent with this requirement, the correlation between $D I V$ and the IND_LOAN_INTENSITY variable is only 0.02 , but the correlation with LOAN_INTENSITY is 0.23 . The economic rationale for using IND_LOAN_INTENSITY as an instrument is that different industries may have different production technologies requiring differing reliance on bank loan financing. This would be largely independent of dividend payout policy, which would not necessarily be fixed across

\footnotetext{
${ }^{12}$ The results are robust to changes from maximum likelihood estimation to two stage estimation and v.v., as well as to unadjusted standard errors.
} 
industry. That is, financing decisions would be largely dependent on industry characteristics and not directly related to dividend payout policy. Similarly, John and Knyazeva (2006) use an industry measure as an instrumental variable.

The NO_LEAD measures the number of relationship banks for each borrower, measuring the exclusivity, and therefore, hold-up power of the lead bank relationship. The correlation of NO_LEAD with DIV is 0.12 , as compared to 0.06 with LOAN_INTENSITY. However, this univariate correlation does not represent the extent of the impact of NO_LEAD on LOAN_INTENSITY, since the relationship could be expected to be more complex than represented in a simple correlation coefficient. That is, the larger the number of lead arrangers, the lower the loan intensity for each bank lender, but the more dependent the borrower is on bank lending overall as a source of financing, and therefore the more effective the bank monitoring mechanism. Thus, the NO_LEAD variable would impact loan terms, but would not directly impact the borrower's dividend policy, thereby satisfying conditions for an instrumental variable.

We perform formal tests to determine whether the chosen instruments are correlated to the structural equation's error term LOAN_INTENSITY. To test whether the instruments are exogenous to the structural equation we implement the Sargan (1958) test when the structural equation is OLS and the Amemiya-Lee-Newey minimum chi-sq statistic (Lee (1992) and Newey (1987)) when the structural equation is Probit or Tobit. These test the null hypotheses that the instruments are valid, i.e., the chosen instruments are not correlated to the structural equation's error term and therefore correctly excluded from the structural equation. Panel B reports the results of these tests. For all three models, we fail to reject the null hypothesis. This affirms the exogeneity of the instruments.

\section{INSERT TABLE 5 Panels A and B AROUND HERE}

Further, we test whether our models are under identified or weak. ${ }^{13}$ The Anderson (1951) canonical correlation LR statistic is estimated to test the null hypothesis that the instruments are underidentified. The Anderson canonical correlation LR statistic for all models, reported in Table 5 , are significantly different from zero, rejecting the null of underidentification. The CraggDonald (1993) statistic is estimated to test for weak instruments. The Cragg-Donald statistics for

\footnotetext{
${ }^{13}$ These tests are implemented in the context of a linear IV two-stage least squares estimation. We are not aware of similar tests of under identification or weak instruments that account for Probit or Tobit structural equations. Angrist and Kruger (2001, p. 80) note, "Even if the underlying second-stage relationship is nonlinear, linear instrumental variables estimates such as two-stage least squares typically capture an average effect of economic interest..." Therefore, we implement these tests in our context.
} 
all models, reported in Panel B of Table 5, are above the Stock and Yogo (2005) critical values. ${ }^{14}$ This suggests that our instrumental variables are not weak.

The results of the two-stage IV estimation are reported in Table 6. As in the simple regression tests (presented in Table 4), all coefficients on the LOAN_INTENSITY variable are negative and statistically significant at the 5\% level or better. As an indicator of the economic significance of this result (using column (1) of Table 6), a one standard deviation increase in bank loan intensity (14.81\% -- see Table 1) would suggest a 5.78\% decrease in dividend payout for all firms. Moreover, the signs on the control variables are the same as in Table 4 and are consistent with theory. For example, there is a significantly negative relationship between dividend payouts and the incidence of a dividend restricting covenant, firm growth, risk, probability of default and indebtedness. Moreover, there is a significantly positive relationship between dividend payouts and lagged dividend payout levels, free cash flow and firm asset/income size. Finally, the coefficients on the corporate governance variables are significant and the expected signs, as in Table 4.

\section{INSERT TABLE 6 AROUND HERE}

We have identified two possible explanations for the finding of an inverse relationship between dividend payout policy and bank lending intensity: (1) the corporate governance motivation (banks act as monitors obviating the need for costly dividend pre-commitment to discipline management) and (2) the cash flow protection motivation (banks' protection of their senior claim on the firm's assets). Table 6 provides some evidence that both mechanisms are at work. That is, we find that after controlling for corporate governance mechanisms (insider stake and institutional block holdings), there is still an inverse relationship between dividend payout policy and bank lending intensity. That is, if bank monitoring was a substitute for institutional monitoring or managerial self-monitoring (via high stock holdings), then including these variables would negate the significance of the loan intensity variable. Despite controlling for this tradeoff between corporate governance mechanisms and dividend policy as monitoring mechanisms, Table 6 shows the persistence of an inverse relationship between dividend payout and bank lending intensity, consistent with the existence of the cash flow protection motivation for bank lenders.

\footnotetext{
${ }^{14}$ The Cragg-Donald statistic is significantly different from zero at the $5 \%$ significance level of a Wald test for the desired maximal size of 10. See Table 2 of Stock and Yogo (2005).
} 


\section{Matching Tests}

\subsection{Matching methodology}

Panel A of Table 5 presents results that reject the null hypothesis that LOAN_INTENSITY is exogenous. Therefore, in Section 3, we use an IV approach to address the endogeneity of the firm's reliance on bank loan financing. In this section, we demonstrate the robustness of our results by using propensity score matching to control for endogeneity. Propensity score matching (see Rosenbaum and Rubin (1983, 1985a, 1985b)) involves estimation of the propensity of one of two states (treatment or control) based on selected determinants of participation in the states, and then uses a matching procedure to identify firms that have similar propensity but differ in their participation in the states. Examples of the use of propensity matching in the finance literature includes Bharath, Dahiya, Saunders, and Srinivasan (2008), Drucker and Puri (2005), Gottesman and Roberts (2007), Heckman, Ichimura, and Todd (1998), Michaely and Roberts (2007), and Saunders and Steffen (2008). In our context, the treatment is high loan intensity, while the control is low loan intensity. Hence, our method determines the propensity score for firms being characterized as high or low loan intensity, and then matches the high loan intensity "treatments" to the low loan intensity "controls" on the basis of these propensity scores.

One important consideration in our propensity score matching implementation is that we determine whether an observation is in the treatment or control on the basis of LOAN_INTENSITY, a continuous variable, rather than a $1 / 0$ dummy. To characterize a given observation as treatment or control, we rank observations based on LOAN_INTENSITY and categorize observations as a treatment or control based on its relative rank. Due to the continuous nature of this categorization, we characterize observations as treatments or controls using the median as the cutoffs. That is, we categorize an observation as belonging to the treatment, i.e., high loan intensity, if its LOAN_INTENSITY level is above the median. We correspondingly categorize an observation as belonging to the control, i.e., low loan intensity, if its LOAN_INTENSITY level is below the median.

To develop propensity scores for each observation, we estimate the following Probit model. 
LOAN_INTENSITY_CATEGORY $=$ LDIV, COVENANT, GROWTH, LNASSETS, INCOME, LEVERAGE, FCF, MB, TAXES, RISK, INTANGIBLE, PROB_KMV, DEBT_DUM, INSIDER, INSIDER^2, INSTHLD, IND_LOAN_INTENSITY, NO_LEAD, industry dummies, fiscal year dummies $+e$

In the above model, LOAN_INTENSITY_CATEGORY is a dummy variable that is equal to one if the observation has been categorized as high loan intensity, and is equal to zero if the observation has been categorized as low loan intensity. All other variables are as defined earlier. The results of the above estimation are presented in Table 7 for each categorization.

The propensity score for each observation is calculated using the Probit model in equation (3). A propensity score of $80 \%$ indicates that the given observation has an $80 \%$ chance of being high loan intensity given the specified determinants. The average propensity score for those observations categorized as high loan intensity is 0.6081 , and 0.3937 for those categorized as low loan intensity.

To ensure that propensity scores overlap, we eliminate those high loan intensity observations whose propensity scores are outside of the range of propensity scores associated with low loan intensity observations. This eliminates 27 high loan intensity treatment observations. Matches are then identified for the remaining 7,585 treatments.

The results of the Probit estimation of equation (3) are shown in Table 7. Consistent with our choice of IND_LOAN_INTENSITY and NO_LEAD as instrumental variables in Section 3.2, these variables are statistically significantly (at the $1 \%$ level) and positively related to LOAN_INTENSITY.

\section{INSERT TABLE 7 AROUND HERE}

We next match the high loan intensity treatments to the low loan intensity controls. The method we use to implement the matching is nearest neighbor matching. As the name suggests, the nearest neighbor methodology matches the control with the propensity score closest to treatment as the match. Nearest neighbor matching can be implemented with replacement or without. If replacement is permitted, then a control used as a match can be reused if it happens to be the nearest neighbor of another treatment as well, while the technique without replacement uses each control only one time. Given that our treatment and control samples are approximately the same size, matching without replacement would result in comparing the treatment to the 
entire set of controls - effectively, an unmatched sample. Hence, our matching is performed with replacement.

In its simplest form nearest neighbor matching identifies a single control that is identified as the match, $\mathrm{NN}(1)$. An alternative is $k$-nearest neighbor matching, which can be implemented as well, where the $k$-nearest neighbors are identified, and matches are performed relative to this group of neighbors. We implement nearest neighbor matching using 50 and 100 (NN(50) and $\mathrm{NN}(100))$ nearest neighbors as well as $\mathrm{NN}(1)$.

\subsection{Results of the matching tests}

The results of the matching tests are presented in Table 8. Results are reported for NN(1), $\mathrm{NN}(50), \mathrm{NN}(100)$, and for the unmatched sample. For each, the mean value of the high loan intensity treatment and the low loan intensity matched control are reported, as well as the difference, significance, and standard deviation. These results are reported for both the DIV and DIVABOVEZERODUMMY variables. Table 8 shows that there is a statistically significant (at the $5 \%$ level or better) inverse relationship between both overall dividend payout and the dummy variable specifications and loan intensity under all matching methodologies.

\section{INSERT TABLE 8 AROUND HERE}

The results of the matching tests are also consistent with the two-stage IV analysis in terms of the two hypothesized motivations for the inverse relationship between dividend payout and bank lending intensity: the corporate governance motivation and the cash flow protection motivation. We incorporate corporate governance variables in our propensity score estimation performed to match the observations in the sample. As shown in Table 7, institutional block holding (INSTHLD) corporate governance mechanisms had a statistically significant (at the $1 \%$ level) positive impact on the propensity score. Even after taking that into account, Table 8 shows a statistically significant (at the $5 \%$ level or better) inverse relationship between loan intensity and dividend payout policy, suggesting a complementary role for corporate governance mechanisms and bank monitoring in determining corporate dividend policies.

\section{Conclusion}

We document the inverse relationship between dividend payout policy and the dependence of the firm on bank financing. That is, the more reliant a firm is on bank loans, the lower their dividend payout, ceteris paribus. We identify two complementary reasons for this effect. (1) monitoring by relationship banks acts as an effective governance mechanism, thereby reducing 
the gains from pre-committing to costly dividend payouts (the corporate governance motivation) and (2) banks limit dividend payouts to shareholders in order to protect the integrity of their senior claim on the firm's assets (the cash flow protection motivation). The inverse relationship persists even after controlling for corporate governance mechanisms such as insider stake and institutional block holdings, suggesting that both motivations impact corporate dividend policies. We employ two independent methodologies in order to test the robustness of this result. We utilize a two-stage instrumental variables analysis in order to control for the endogeneity in dividend payout policy. Moreover, we utilize a matched pair sampling technique to further investigate the relationship between dividend payout policy and bank lending intensity. The inverse relationship between dividend payout and bank lending intensity is robust to all methodologies and variable definitions. 


\section{Appendix 1: Estimation of the Implied Probability of Default}

The implied probability of default is estimated as follows:

$I D P_{i t}=N\left(-D D_{i t}\right)$

where

$D D_{i t}=\left[\ln \left(V_{A i t} / L_{i t}\right)+T\left(r_{t}+0.5 \sigma^{2}{ }_{A i t}\right)\right] / \sigma_{A i t} \sqrt{T}$.

$V_{A i t}$ is the firm's asset value, $\sigma_{A i t}$ is the firm's volatility, and the parameter $\mu$ is estimated through calculating the average change in $\log \left(V_{\text {Ait }}\right)$, and represents the instantaneous drift of $V_{A}$. We identify $V_{A i t}$ and $\sigma_{A i t}$ using Newton's nonlinear approximation technique to solve the following system of equations:

$V_{E i t}=V_{A i t} N\left(D D_{i t}\right)-e^{-r_{t} T} L_{i t} N\left(D D_{i t}-\sigma_{A i t} \sqrt{T}\right)$

$\sigma_{E i t}=\frac{V_{A i t}}{V_{E i t}} N\left(D D_{i t}\right) \sigma_{A i t}$

where $\mathrm{N}(\mathrm{)})$ is the normal distribution,

$$
\begin{aligned}
& D_{1 i t}=\left[\ln \left(V_{A i t} / L_{i t}\right)+T\left(r_{t}+0.5 \sigma_{A i t}^{2}\right)\right] / \sigma_{A i t} \sqrt{T}, \\
& D_{2 t i}=D_{1 t i}-\sigma_{A i t} \sqrt{T},
\end{aligned}
$$

$V_{E i t}$ is the borrower $i$ 's equity market value at time $t$, measured as the product of the borrower's stock price and shares outstanding at the end of fiscal year $t$; $L_{i t}$ is the borrower's total liabilities; $r_{t}$ is the risk free rate, proxied by the rate of return on three-month Treasury bills.; $\sigma_{E i t}$ is the equity volatility, estimated as the standard deviation of daily stock returns in fiscal year $\mathrm{t}$; and $\mathrm{T}$ is the one year estimation period. We then convert the daily equity volatility into an annual 
measure by assuming that there are 252 trading days in a year. To be included in the estimation, each borrower must have at least 200 daily returns. 


\section{References}

Aivazian, V.A., L. Booth and S. Cleary, 2006, "Dividend Smoothing and Debt Ratings," Journal of Financial and Quantitative Analysis, vol. 41, pp.439-453.

Allen, L. and A. Gottesman, 2006, “The Informational Efficiency of the Equity Market As Compared to the Syndicated Bank Loan Market," Journal of Financial Services Research, vol. 30, pp. 5-42.

Anderson, T.W., 1951, "Estimating linear restrictions on regression coefficients for multivariate normal distributions," Annals of Mathematical Statistics, vol. 22, pp. 327-51.

Angrist, J.D. and A. Kruger, 2001, "Instrumental variables and the search for identification: from supply and demand to natural experiments," Journal of Economic Perspectives, vol. 15, 69-85.

Barnea, A., RA Haugen and LW Senbet, 1981, "Market Imperfections, Agency Problems and Capital Structure: A Review," Financial Management, Vol. 10, No. 3, pp. 7-22.

Benartzi, S., G. Grullon, R. Michaely and R. Thaler, 2005, "Dividend Changes Do Not Signal Changes in Future Profitability," Journal of Business, vol. 78, pp. 1659-1682.

Benartzi, S., R. Michaely and R. Thaler, 1997, "Do Changes in Dividends Signal the Future or the Past?” Journal of Finance, vol. 52, pp. 1007-1034.

Bharath, S., S. Dahiya, A. Saunders and A. Srinivasan, 2008, "Lending Relationships and Loan Contract Terms: Does Size Matter?" Working paper.

Bharath, S., S. Dahiya, A. Saunders and A. Srinivasan, 2007, "So What Do I Get? The Bank's View of Lending Relationships," Journal of Financial Economics, vol. 85, pp. 368-419.

Cragg, J.G. and S.G. Donald, 1993, "Testing identfiability and specification in instrumental variables models," Econometric Theory, vol. 9, pp. 222-240.

Cremer M. and V. Nair, 2005, "Governance Mechanisms and Equity Prices," Journal of Finance, vol. 60, pp. 2859-2894.

Drucker, S., and M. Puri, 2005, "On the Benefits of Concurrent Lending and underwriting," Journal of Finance, vol. 60, pp. 2763-2800.

Durbin, J., 1954, "Errors in variables," Review of the International Statistical Institute, vol. 22, pp. 23-32.

Easterbrook, F., 1984, "Two Agency-Cost Explanations of Dividends," American Economic Review, vol. 74, pp. 650-659. 
Gottesman, A.A. and G.S. Roberts, 2007, "Loan rates and collateral," Financial Review, vol. 42, 2007, pp. 401-427.

Guay, W. and J. Harford, 2000, "The Cash-Flow Permanence and Information Content of Dividend Increases versus Repurchases," Journal of Financial Economics, vol. 57, pp. 385-415.

Hausch, D.B. and J.B. Seward, 1993, "Signaling with Dividends and Share Repurchase," Review of Financial Studies, vol. 6, pp. 121-154.

Hausman, J., 1978, “Specification tests in econometrics," Econometrica, vol. 46, pp. 1251-1271.

Heckman, J.J., H. Ichimura and P.E. Todd, 1998, "Matching as an econometric evaluation estimator," Review of Economic Studies, vol. 65, 261-294.

Jagnnathan, M., C.P. Stephens and M.S. Weisbach, 2000, "Financial Flexibility and the Choice Between Dividends and Stock Repurchases," Journal of Financial Economics, vol. 57, pp. 355384.

Jensen, M. 1986, "Agency Costs of Free Cash Flow, Corporate Finance and Takeovers," American Economic Review, vol. 76, pp. 323-329.

Jensen, M. and W. Meckling, 1976, "Theory of the Firm: Managerial Behavior, Agency Costs and Ownership Structure,” Journal of Financial Economics, vol. 3, pp. 305-360.

John, K. and A. Knyazeva, 2006, "Payout Policy, Agency Conflicts and Corporate Governance," New York University working paper.

Knyazeva, A., 2007, "Delivering on the Dividend Promise: Corporate Governance, Managerial Incentives and Dynamic Dividend Behavior," New York University working paper.

Lee, L., 1992, “Amemiya's Generalized Least Squares and Tests of Overidenfication in Simultaneous Equation Models with Qualitative or Limited Dependent Variables," Econometric Reviews, vol. 11, pp. 319-328.

Lie, E. and J. McConnell, 1998, "Earnings Signals in Fixed-Price and Dutch Auction SelfTender Offers," Journal of Financial Economics, vol. 49, pp. 161-186.

Liu, Y., S.H. Szewczyk and Z. Zantout, 2008, "Underreaction to Dividend Reductions and Omissions?" Journal of Finance, vol. 63, pp. 987-1020.

McConnell, J. and H. Servaes, 1990, “Additional Evidence on Equity Ownership and Corporate Value," Journal of Financial Economics, vol. 27, pp. 595-612.

Michaely, R., and M. R. Roberts, 2007, "Corporate Dividend Policies: Lessons from private companies", Working paper. 
Miller, M.H. and K. Rock, 1985, "Dividend Policy Under Asymmetric Information,” Journal of Finance, vol. 40, pp. 1031-1051.

Morck, R., A. Shleifer, and R. Vishny, 1988, "Management Ownership and Market Valuation: An Empirical Analysis," Journal of Financial Economics, vol. 20, pp. 293-315.

Newey, W.K., 1987, "Efficient Estimation of Limited Dependent Variable Models with Endogeneous Explanatory Variables," Journal of Econometrics, vol. 36, pp. 231-250.

Parsons, L.S., 2001, "Reducing bias in a propensity score matched-pair sample using greedy matching techniques," Working paper 214-26, Ovation Research Group, Seattle.

Rosenbaum, P., and D. Rubin, 1983, "The central role of the propensity score in observational studies for causal effects," Biometrika, vol. 70, 41-55.

Rosenbaum, P., and D. Rubin, 1985a, "Constructing a control group using multivariate matched sampling methods that incorporate the propensity," American Statistician, vol. 39, 33-38.

Rosenbaum, P., and D. Rubin, 1985b, "The bias due to incomplete matching," Biometrics, vol. 41, 103-116.

Rozeff, M.S., 1982, "Growth, Beta and Agency Costs as Determinants of Dividend Payout Ratios,” Journal of Financial Research, vol. 3, pp. 249-259.

Sargan, J.D., 1958, “The Estimation of Economic Relationships Using Instrumental Variables," Econometrica, vol. 26, pp. 393-415.

Smith, R. J. and R. W. Blundell, 1986, “An exogeneity test for a simultaneous equation Tobit model with an application to labor supply," Econometrica, vol. 54, pp. 679-686.

Saunders, A. and S. Steffen, 2008, "The Cost of Being Private: Evidence from Loan Markets," Working paper.

Stephens, C. and M. Weisbach, 1998, "Actual Share Acquisitions in Open Market Share Repurchase Programs,” Journal of Finance, vol. 53, pp. 313-333.

Stock, J.H. and M. Yogo, 2005, "Testing for weak instruments in linear IV regressions," in D.W.K. Andrews and J.H. Stock, eds., Identification and Inference for Econometric Models: Essays in Honor of Thomas Rothenberg, Cambridge: Cambridge University Press, 2005, pp. 80108.

Stulz, R., 1988, "Managerial Control of Voting Rights," Journal of Financial Economics, vol. 20, pp. 25-59. 
Wruck, K., 1989, "Equity Ownership Concentration and Firm Value," Journal of Financial Economics, vol. 23, pp. 3-28.

Wu, D., 1973, "Alternative tests of independence between stochastic regressors and disturbances," Econometrica, vol. 41, pp. 733-750. 
Table 1: Descriptive Statistics. The number of observations, the mean minimum, maximum, and standard deviation are reported for the variables used in this study. LOAN_INTENSITY is the total amount of loans outstanding provided by banks to the given firm during the previous three fiscal years normalized by the book value of total assets of the firm at the beginning of the given fiscal year $t$. IND_LOAN_INTENSITY is the average LOAN_INTENSITY for the given firm's industry. NO_LEAD is the value-weighted number of leading arrangers of loans originated between year $t-3$ and $t-1$ with maturity after year $t$. DIV is the ratio of cash dividends to the book value of total assets. LDIV is the lag of DIV. DIVABOVEZERO is equal to DIV if DIV is greater than zero and set to missing otherwise. DIVABOVEZERODUMMY is a dummy variable equal to zero if DIV is greater than zero and zero otherwise. COVENANT is a dummy variable that is equal to 1 if a loan deal contains any dividend covenant reported on the DealScan database. GROWTH is the relative changes in net sales from the previous fiscal year. LNASSET is defined as the natural logarithm of the book value of the firm's total assets. INCOME is the given firm's net income. LEVERAGE is the book value of current and long-term debts. FCF is EBITDA minus changes in working capital (current assets minus current liabilities) minus capital expenditure. MB is the ratio of the market value of equity plus the book value of current and long-term debts to the book value of total assets. TAXES is total income tax normalized by EBIT. RISK is the standard deviation of market-adjusted monthly stock returns in the given year $t$. INTANGIBLE is the ratio of intangible assets to total assets. PROB_KMV is the implied probability of default. DEBT_DUM is a dummy variable that is equal to 1 if the firm does not have a debt instrument with an S\&P credit rating and a maturity date after the end of fiscal year $t$. INSTHLD is institutional holding variable, constructed by averaging quarterly institutional ownership data for each year. INSIDER is the natural logarithm of total market value of shares held by firm's management at the end of fiscal year $t$.

\begin{tabular}{lcccc}
\hline Variable & Mean & Minimum & Maximum & Std. Dev. \\
\hline LOAN_INTENSITY & 0.1809 & 0.0138 & 0.7278 & 0.1481 \\
IND_LOAN_INTENSITY & 0.1809 & 0.1155 & 0.3196 & 0.0348 \\
NO_LEAD & 0.5276 & 0.0000 & 2.4849 & 0.7188 \\
DIV & 0.0067 & 0.0000 & 0.0927 & 0.0133 \\
LDIV & 0.0086 & 0.0000 & 0.2212 & 0.0226 \\
DIVABOVEZERODUMMY & 0.4070 & 0.0000 & 1.0000 & 0.4913 \\
COVENANT & 0.5040 & 0.0000 & 1.0000 & 0.5000 \\
GROWTH & 0.1655 & -0.6325 & 2.7621 & 0.3724 \\
LNASSET & 6.1454 & 3.1335 & 10.4003 & 1.6208 \\
INCOME & 0.0087 & -0.8235 & 0.2766 & 0.1319 \\
LEVERAGE & 0.3010 & 0.0000 & 1.1223 & 0.2073 \\
FCF & 0.0479 & -0.6376 & 0.6603 & 0.1469 \\
MB & 1.3817 & 0.2303 & 8.4696 & 1.0530 \\
TAXES & 0.1941 & -6.1395 & 5.5610 & 0.8073 \\
RISK & 0.1328 & 0.0315 & 0.5480 & 0.0778 \\
INTANGIBLE & 0.1367 & 0.0000 & 0.7572 & 0.1742 \\
PROB_KMV & 0.0293 & 0.0000 & 0.6062 & 0.0864 \\
DEBT_DUM & 0.2913 & 0.0000 & 1.0000 & 0.4544 \\
INSIDER & 0.0880 & 0.0000 & 2.9053 & 0.2984 \\
INSTHLD & 0.4747 & 0.0010 & 0.9657 & 0.2547
\end{tabular}


Table 2: Correlations. Correlations between the variables in our sample. Correlations in bold are statistically significant at the $10 \%$ level or better.

LOAN INTENSITY

IND LOAN INTENSITY

NO_LEAD

DIV

LDIV

DIVABOVEZERODUMMY

COVENANT

GROWTH

LNASSET

INCOME

LEVERAGE

FCF

MB

TAXES

RISK

INTANGIBLE

PROB_KMV

DEBT DUM

INSIDER

INSTHLD
(1)
(2) (3)
(5)
(6) (7)
(8)
(9) (10
10) (11)
(12) (13)
$(14$
(15) (16) (17)
(18) (19)

(2) 0.23

(3) $0.06 \quad 0.04$

$\begin{array}{llll}\text { (4) } & (0.13) & 0.02 & 0.12\end{array}$

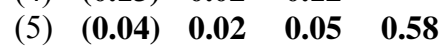

$\begin{array}{llllll}\text { (6) } & \mathbf{( 0 . 1 4 )} & \mathbf{0 . 0 5} & \mathbf{0 . 1 9} & \mathbf{0 . 6 1} & 0.34\end{array}$

$\begin{array}{lllllll}(7) & 0.22 & 0.10 & 0.18 & (0.16) & (0.11) & (0.17)\end{array}$

$\begin{array}{llllllll}(8) & 0.06 & 0.09 & (0.04) & (0.10) & (0.04) & (0.08) & 0.05\end{array}$

$\begin{array}{lllllllll}\text { (9) } & (\mathbf{0 . 1 9}) & \mathbf{0 . 0 5} & \mathbf{0 . 6 4} & \mathbf{0 . 2 8} & \mathbf{0 . 1 3} & \mathbf{0 . 3 9} & \mathbf{0 . 0 1} & 0.00\end{array}$

$\begin{array}{llllllllll}(10) & (0.02) & (0.06) & 0.08 & 0.19 & 0.15 & 0.18 & (0.05) & 0.10 & 0.19\end{array}$

$\begin{array}{lllllllllll}(11) & 0.30 & 0.30 & 0.12 & (0.05) & (0.02) & (0.04) & 0.07 & 0.02 & 0.08 & (0.27)\end{array}$

$\begin{array}{lllllllllllll}(12) & 0.04 & (0.05) & 0.11 & 0.18 & 0.11 & 0.12 & (0.00) & (0.15) & 0.10 & 0.12 & 0.06\end{array}$

$\begin{array}{llllllllllllll}(13) & \mathbf{( 0 . 0 6 )} & (\mathbf{0 . 0 8}) & (0.00) & \mathbf{0 . 1 3} & \mathbf{0 . 1 2} & \mathbf{( 0 . 0 3 )} & (0.01) & \mathbf{0 . 1 9} & \mathbf{0 . 0 3} & \mathbf{0 . 2 1} & \mathbf{( 0 . 1 8} & 0.00\end{array}$

$\begin{array}{llllllllllllll}\text { (14) } & (\mathbf{0 . 0 2}) & \mathbf{( 0 . 0 2 )} & 0.01 & \mathbf{0 . 0 3} & 0.01 & \mathbf{0 . 0 2} & (0.01) & \mathbf{0 . 0 1} & \mathbf{0 . 0 2} & \mathbf{0 . 1 0} & \mathbf{( 0 . 0 8 )} & \mathbf{0 . 0 4} & \mathbf{0 . 0 5}\end{array}$

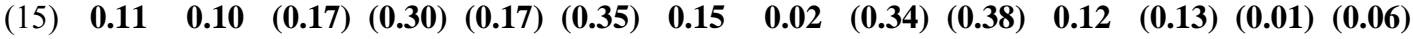

$\begin{array}{llllllllllllllllll}(16) & 0.14 & 0.02 & 0.23 & (0.05) & (0.04) & (0.03) & 0.18 & 0.09 & 0.14 & 0.00 & 0.12 & 0.18 & (0.00) & 0.02 & (0.01)\end{array}$

$\begin{array}{lllllllllllllllll}(17) & 0.12 & 0.10 & (0.08) & (0.14) & (0.08) & (0.18) & 0.05 & (0.10) & (0.20) & (0.41) & 0.34 & 0.07 & (0.21) & (0.06) & 0.51 & 0.01\end{array}$

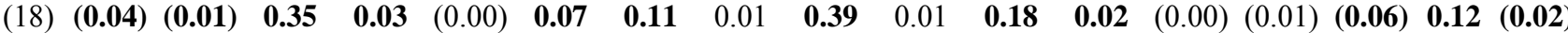

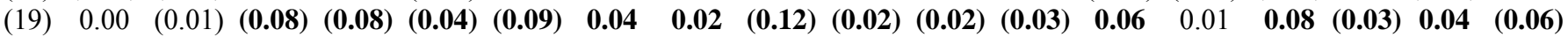

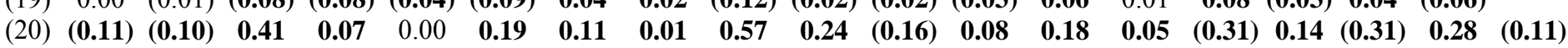


Table 3: Univariate relation between loan intensity and dividends. Observations are ranked on the basis of LOAN_INTENSITY and placed into one of 20 groupings on this basis. The mean values of DIV and DIVABOVEZERO are reported for each grouping.

\begin{tabular}{|c|c|c|c|c|}
\hline LOAN_INTENSITY & & MEAN & & MEAN \\
\hline$\overline{\text { GROUP }}$ & $\mathrm{N}$ & LOAN INTENSITY & MEAN DIV & DIVABOVEZERODUMMY \\
\hline 1 & 761 & 0.0198 & 0.0089 & 0.4915 \\
\hline 2 & 762 & 0.0331 & 0.0081 & 0.4843 \\
\hline 3 & 762 & 0.0442 & 0.0095 & 0.5367 \\
\hline 4 & 762 & 0.0552 & 0.0089 & 0.5026 \\
\hline 5 & 762 & 0.0660 & 0.0097 & 0.5144 \\
\hline 6 & 762 & 0.0767 & 0.0080 & 0.4672 \\
\hline 7 & 762 & 0.0885 & 0.0081 & 0.4672 \\
\hline 8 & 762 & 0.1006 & 0.0071 & 0.4318 \\
\hline 9 & 762 & 0.1137 & 0.0085 & 0.4646 \\
\hline 10 & 761 & 0.1281 & 0.0073 & 0.4074 \\
\hline 11 & 762 & 0.1445 & 0.0064 & 0.4094 \\
\hline 12 & 762 & 0.1629 & 0.0065 & 0.3871 \\
\hline 13 & 762 & 0.1830 & 0.0064 & 0.3898 \\
\hline 14 & 762 & 0.2057 & 0.0055 & 0.3766 \\
\hline 15 & 762 & 0.2322 & 0.0046 & 0.3136 \\
\hline 16 & 762 & 0.2634 & 0.0042 & 0.3215 \\
\hline 17 & 762 & 0.3016 & 0.0041 & 0.2992 \\
\hline 18 & 762 & 0.3545 & 0.0042 & 0.2769 \\
\hline 19 & 762 & 0.4403 & 0.0039 & 0.3110 \\
\hline 20 & 761 & 0.6037 & 0.0033 & 0.2878 \\
\hline
\end{tabular}


Table 4: Simple Regression Estimation. The relation between dividends and loan intensity is tested using the following model: DIVIDEND MEASURE $=\alpha+\gamma \cdot \ln ($ LOAN_INTENSITY $)+\beta^{\prime} \cdot$ CONTROLS $+e$, where CONTROLS $=[$ LDIV, COVENANT, GROWTH, LNASSETS, INCOME, LEVERAGE, FCF, MB, TAXES, RISK, INTANGIBLE, PROB KMV, DEBT_DUM, INSIDER, INSIDER_SQ, INSTHLD, industry dummies, fiscal year dummies]. Three separate specifications of the dividend measure are DIV, $\ln (\mathrm{DIV})$, and DIVABOVEZERODUMMY. LOAN_INTENSITY is assumed to be exogenous. All observations in the sample are used when either DIV or DIVABOVEZERODUMMY is the dependent variable, while only observations where DIV is greater than zero are used when $\ln (\mathrm{DIV})$ is the dependent. Tobit estimation is implemented when DIV is the dependent variable. Probit estimation when DIVABOVEZERODUMMY is the dependent. When $\ln$ (DIV) is the dependent, we implement ordinary least squares. Standard errors are adjusted for the possibility of heteroskedasticity and firm clustering. Significance levels are indicated by $*, * *$ and $* * *$ that represent $10 \%, 5 \%$ and $1 \%$ level, respectively.

\begin{tabular}{|c|c|c|c|}
\hline $\begin{array}{l}\text { Sample } \\
\text { Model } \\
\text { Dependent }\end{array}$ & $\begin{array}{l}\text { All obs. } \\
\text { Tobit } \\
\text { DIV }\end{array}$ & $\begin{array}{c}\text { DIV }>0 \\
\text { OLS } \\
\ln (\mathrm{DIV})\end{array}$ & $\begin{array}{c}\text { All obs. } \\
\text { Probit } \\
\text { DIV }>0 \text { dummy }\end{array}$ \\
\hline LOG_LOAN_INTENSITY & $\begin{array}{c}-0.0011 * * * \\
(0.0003)\end{array}$ & $\begin{array}{l}-0.0431^{*} \\
(0.0222)\end{array}$ & $\begin{array}{c}-0.0734 * * * \\
(0.0239)\end{array}$ \\
\hline LDIV & $\begin{array}{c}0.3726 * * * \\
(0.0225)\end{array}$ & $\begin{array}{c}19.0027 * * * \\
(1.6832)\end{array}$ & $\begin{array}{c}15.7050 * * * \\
(1.4786)\end{array}$ \\
\hline COVENANT & $\begin{array}{c}-0.0033 * * * \\
(0.0006)\end{array}$ & $\begin{array}{c}-0.1508 * * * \\
(0.0392)\end{array}$ & $\begin{array}{c}-0.2483 * * * \\
(0.0428)\end{array}$ \\
\hline GROWTH & $\begin{array}{c}-0.0044 * * * \\
(0.0007)\end{array}$ & $\begin{array}{c}-0.4444 * * * \\
(0.0583)\end{array}$ & $\begin{array}{c}-0.1683 * * * \\
(0.0436)\end{array}$ \\
\hline LNASSET & $\begin{array}{c}0.0038 * * * \\
(0.0003)\end{array}$ & $\begin{array}{c}0.0642 * * * \\
(0.0169)\end{array}$ & $\begin{array}{c}0.3166^{* * * *} \\
(0.0203)\end{array}$ \\
\hline INCOME & $\begin{array}{c}0.0088 * * * \\
(0.0031)\end{array}$ & $\begin{array}{c}0.095 \\
(0.2738)\end{array}$ & $\begin{array}{c}0.3409 * * \\
(0.1675)\end{array}$ \\
\hline LEVERAGE & $\begin{array}{l}-0.0035^{*} \\
(0.0020)\end{array}$ & $\begin{array}{c}-0.8307 * * * \\
(0.1514)\end{array}$ & $\begin{array}{c}-0.3521 * * * \\
(0.1225)\end{array}$ \\
\hline FCF & $\begin{array}{c}0.0190 * * * \\
(0.0022)\end{array}$ & $\begin{array}{c}0.9271 * * * \\
(0.1810)\end{array}$ & $\begin{array}{c}0.6647 * * * \\
(0.1143)\end{array}$ \\
\hline MB & $\begin{array}{c}0.0011 * * * \\
(0.0004)\end{array}$ & $\begin{array}{c}0.0870 * * * \\
(0.0327)\end{array}$ & $\begin{array}{c}-0.0541 * * \\
(0.0239)\end{array}$ \\
\hline TAXES & $\begin{array}{c}0.0003 \\
(0.0002)\end{array}$ & $\begin{array}{c}0.0276 \\
(0.0243)\end{array}$ & $\begin{array}{c}0.0063 \\
(0.0164)\end{array}$ \\
\hline RISK & $\begin{array}{c}-0.0759 * * * \\
(0.0064)\end{array}$ & $\begin{array}{c}-3.6420 * * * \\
(0.4353)\end{array}$ & $\begin{array}{c}-3.8768 * * * \\
(0.3697)\end{array}$ \\
\hline INTANGIBLE & $\begin{array}{c}-0.0064 * * * \\
(0.0019)\end{array}$ & $\begin{array}{c}-0.2304 \\
(0.1624)\end{array}$ & $\begin{array}{l}-0.2091 \\
(0.1397)\end{array}$ \\
\hline PROB_KMV & $\begin{array}{c}-0.0134 * * * \\
(0.0050)\end{array}$ & $\begin{array}{l}-0.5114 \\
(0.3778)\end{array}$ & $\begin{array}{c}-0.6911^{* *} \\
(0.2902)\end{array}$ \\
\hline DEBT_DUM & $\begin{array}{c}-0.0015^{* *} \\
(0.0006)\end{array}$ & $\begin{array}{c}-0.1169 * * * \\
(0.0423)\end{array}$ & $\begin{array}{c}-0.1160 * * \\
(0.0482)\end{array}$ \\
\hline INSIDER & $\begin{array}{c}-0.0070^{* * *} \\
(0.0022)\end{array}$ & $\begin{array}{c}-0.6259^{* * *} \\
(0.2108)\end{array}$ & $\begin{array}{l}-0.1606 \\
(0.1388)\end{array}$ \\
\hline INSIDER^2 & $\begin{array}{l}0.0014^{*} \\
(0.0008)\end{array}$ & $\begin{array}{c}0.2147 * * * \\
(0.0776)\end{array}$ & $\begin{array}{c}0.0028 \\
(0.0566)\end{array}$ \\
\hline INSTHLD & $\begin{array}{c}-0.0092 * * * \\
(0.0017)\end{array}$ & $\begin{array}{c}-0.4488 * * * \\
(0.1242)\end{array}$ & $\begin{array}{l}-0.2123^{*} \\
(0.1124)\end{array}$ \\
\hline _cons & $\begin{array}{c}-0.0145 * * * \\
(0.0026)\end{array}$ & $\begin{array}{c}-4.6100 * * * \\
(0.1679)\end{array}$ & $\begin{array}{c}-1.6159 * * * \\
(0.1843)\end{array}$ \\
\hline $\begin{array}{l}\text { Year dummies } \\
\text { Industry dummies }\end{array}$ & $\begin{array}{l}\text { YES } \\
\text { YES }\end{array}$ & $\begin{array}{l}\text { YES } \\
\text { YES }\end{array}$ & $\begin{array}{l}\text { YES } \\
\text { YES }\end{array}$ \\
\hline $\begin{array}{l}\text { Chi-square } \\
\text { R-square }\end{array}$ & $1,816.83$ & $\begin{array}{c}0.3688 \\
6202\end{array}$ & $1,216.71$ \\
\hline
\end{tabular}


Table 5: Tests of endogeneity and instruments. Panel A tests endogeneity of LOAN_INTENSITY in the regression estimation DIVIDEND MEASURE $=\alpha+\gamma \cdot \ln ($ LOAN_INTENSITY $)+\beta^{\prime} \cdot$ CONTROLS $+\bar{e}$. The Durbin-Wu-Hausman test (Davidson and MacKinnon, 1993, Durbin, 1954, Hausman, 1978 and Wu, 1973) is implemented for the OLS regression model and Smith and Blundell (1986) for the Probit and Tobit models. Panel B tests whether the instruments used in the method of instrumental variables, IND_LOAN_INTENSITY and NO_LEAD, are exogenous to the structural equation. The Sargan (1958) test is performed when the structural equation is OLS and the Amemiya-Lee-Newey minimum chi-sq statistic (Lee (1992) and Newey (1987)) when the structural equation is Probit or Tobit. The Anderson (1951) canonical correlation LR statistic is estimated to test whether the instruments are underidentified. The Cragg-Donald (1993) statistic is estimated to test for weak instruments, and the statistic is compared to the Stock and Yogo (2005) critical values.

\section{Panel A}

\begin{tabular}{lccc}
\hline & DIV & $\ln ($ DIV) & DIVABOVEZERODUMMY \\
\hline Smith-Blundell statistic & 11.433 & & 4.271 \\
Durbin-Wu-Hausman statistic & & 4.658 & \\
P-value & 0.000 & 0.031 & 0.039 \\
\hline
\end{tabular}

Panel B

\begin{tabular}{lccc}
\hline & DIV & $\ln (\mathrm{DIV})$ & DIVABOVEZERODUMMY \\
\hline Amemiya-Lee-Newey & 0.465 & & 0.800 \\
Sargan statistic & & 0.024 & \\
P-value & 0.4955 & 0.876 & 0.371 \\
\hline Anderson canonical correlation LM statistic & 952.602 & 346.121 & 952.602 \\
P-value & 0.000 & 0.000 & 0.0000 \\
\hline Cragg-Donald statistic & 506.729 & 182.068 & 506.729 \\
Stock Yogo critical values, maximal size of & & & \\
10, of a 5\% Wald test & 19.93 & 19.93 & 19.93 \\
\hline
\end{tabular}


Table 6: Method of Instrumental Variables. The relation between dividends and loan intensity is tested using the following model: DIVIDEND MEASURE $=\alpha+\gamma \cdot \ln ($ LOAN_INTENSITY $)+\beta^{\prime} \cdot$ CONTROLS $+e$, where CONTROLS $=[$ LDIV, COVENANT, GROWTH, LNASSETS, INCOME, LEVERAGE, FCF, MB, TAXES, RISK, INTANGIBLE, PROB KMV, DEBT_DUM, INSIDER, INSIDER_SQ, INSTHLD, industry dummies, fiscal year dummies]. Three separate specifications of the dividend measure are DIV, $\ln (\mathrm{DIV})$, and DIVABOVEZERODUMMY. LOAN_INTENSITY is assumed to be endogenous. The method of instrumental variables is implemented where the instrumental variables are IND_LOAN_INTENSITY and NO_LEAD. All observations in the sample are used when either DIV or DIVĀBOVEZERODUMMY is the dependent variable, while only observations where DIV is greater than zero are used when $\ln (\mathrm{DIV})$ is the dependent. IV Tobit estimation is implemented when DIV is the dependent variable. IV Probit estimation when DIVABOVEZERODUMMY is the dependent. When $\ln (\mathrm{DIV})$ is the dependent, we implement ordinary IV. Standard errors are adjusted for the possibility of heteroskedasticity and firm clustering. Significance levels are indicated by $*, * *$ and $* * *$ that represent $10 \%, 5 \%$ and $1 \%$ level, respectively.

\begin{tabular}{|c|c|c|c|}
\hline $\begin{array}{l}\text { Sample } \\
\text { Model } \\
\text { Dependent }\end{array}$ & $\begin{array}{l}\text { All obs. } \\
\text { IV tobit } \\
\text { DIV }\end{array}$ & $\begin{array}{c}\text { DIV }>0 \\
\text { IV } \\
\operatorname{Ln}(\text { DIV })\end{array}$ & $\begin{array}{c}\text { All obs. } \\
\text { IV probit } \\
\text { DIV }>0 \text { dummy }\end{array}$ \\
\hline LOG_LOAN_INTENSITY & $\begin{array}{c}-0.0039^{* * *} \\
(0.0012)\end{array}$ & $\begin{array}{c}-0.1988^{* *} \\
(0.0945)\end{array}$ & $\begin{array}{c}-0.2008 * * \\
(0.0949)\end{array}$ \\
\hline LDIV & $\begin{array}{c}0.3734 * * * \\
(0.0224)\end{array}$ & $\begin{array}{c}18.9853 * * * \\
(1.6519)\end{array}$ & $\begin{array}{c}15.6634 * * * \\
(1.4664)\end{array}$ \\
\hline COVENANT & $\begin{array}{c}-0.0020 * * * \\
(0.0008)\end{array}$ & $\begin{array}{l}-0.0873^{*} \\
(0.0514)\end{array}$ & $\begin{array}{c}-0.1873^{* * *} \\
(0.0589)\end{array}$ \\
\hline GROWTH & $\begin{array}{c}-0.0044 * * * \\
(0.0007)\end{array}$ & $\begin{array}{c}-0.4296 * * * \\
(0.0598)\end{array}$ & $\begin{array}{c}-0.1651 * * * \\
(0.0436)\end{array}$ \\
\hline LNASSET & $\begin{array}{c}0.0033 * * * \\
(0.0003)\end{array}$ & $\begin{array}{c}0.0331 \\
(0.0255)\end{array}$ & $\begin{array}{c}0.2925 * * * \\
(0.0278)\end{array}$ \\
\hline INCOME & $\begin{array}{c}0.0108 * * * \\
(0.0032)\end{array}$ & $\begin{array}{c}0.1346 \\
(0.2745)\end{array}$ & $\begin{array}{c}0.4299 * * \\
(0.1816)\end{array}$ \\
\hline LEVERAGE & $\begin{array}{l}-0.0004 \\
(0.0024)\end{array}$ & $\begin{array}{c}-0.6657 * * * \\
(0.1783)\end{array}$ & $\begin{array}{c}-0.214 \\
(0.1599)\end{array}$ \\
\hline FCF & $\begin{array}{c}0.0197 * * * \\
(0.0022)\end{array}$ & $\begin{array}{c}0.9799 * * * \\
(0.1838)\end{array}$ & $\begin{array}{c}0.6885 * * * \\
(0.1160)\end{array}$ \\
\hline MB & $\begin{array}{c}0.0010 * * * \\
(0.0004)\end{array}$ & $\begin{array}{c}0.0847 * * * \\
(0.0324)\end{array}$ & $\begin{array}{c}-0.0590 * * \\
(0.0241)\end{array}$ \\
\hline TAXES & $\begin{array}{c}0.0003 \\
(0.0003)\end{array}$ & $\begin{array}{c}0.0308 \\
(0.0242)\end{array}$ & $\begin{array}{c}0.0069 \\
(0.0165)\end{array}$ \\
\hline RISK & $\begin{array}{c}-0.0748 * * * \\
(0.0064)\end{array}$ & $\begin{array}{c}-3.5008^{* * * *} \\
(0.4488)\end{array}$ & $\begin{array}{c}-3.8133^{* * *} \\
(0.3729)\end{array}$ \\
\hline INTANGIBLE & $\begin{array}{c}-0.0046^{* * *} \\
(0.0021)\end{array}$ & $\begin{array}{l}-0.1325 \\
(0.1803)\end{array}$ & $\begin{array}{l}-0.1202 \\
(0.1492)\end{array}$ \\
\hline PROB_KMV & $\begin{array}{c}-0.0152^{* * * *} \\
(0.0050)\end{array}$ & $\begin{array}{l}-0.6833^{*} \\
(0.3613)\end{array}$ & $\begin{array}{c}-0.7631^{* * *} \\
(0.2908)\end{array}$ \\
\hline DEBT_DUM & $\begin{array}{c}-0.0016^{* * *} \\
(0.0006)\end{array}$ & $\begin{array}{c}-0.1199 * * * \\
(0.0421)\end{array}$ & $\begin{array}{c}-0.1177 * * \\
(0.0482)\end{array}$ \\
\hline INSIDER & $\begin{array}{c}-0.0070 * * * \\
(0.0022)\end{array}$ & $\begin{array}{c}-0.6573 * * * \\
(0.2143)\end{array}$ & $\begin{array}{l}-0.1633 \\
(0.1379)\end{array}$ \\
\hline INSIDER $^{\wedge} 2$ & $\begin{array}{l}0.0014 * \\
(0.0008)\end{array}$ & $\begin{array}{c}0.2209 * * * \\
(0.0784)\end{array}$ & $\begin{array}{c}0.003 \\
(0.0562)\end{array}$ \\
\hline INSTHLD & $\begin{array}{c}-0.0085^{* * *} \\
(0.0017)\end{array}$ & $\begin{array}{c}-0.4215^{* * *} \\
(0.1247)\end{array}$ & $\begin{array}{l}-0.1789 \\
(0.1144)\end{array}$ \\
\hline _cons & $\begin{array}{c}-0.0196 * * * \\
(0.0032)\end{array}$ & $\begin{array}{c}-4.8754 * * * \\
(0.2240)\end{array}$ & $\begin{array}{c}-1.8452^{* * *} \\
(0.2372)\end{array}$ \\
\hline $\begin{array}{l}\text { Year dummies } \\
\text { Industry dummies }\end{array}$ & $\begin{array}{l}\text { YES } \\
\text { YES }\end{array}$ & $\begin{array}{l}\text { YES } \\
\text { YES }\end{array}$ & $\begin{array}{l}\text { YES } \\
\text { YES }\end{array}$ \\
\hline Chi-square & $1,797.96$ & & $1,235.15$ \\
\hline $\begin{array}{l}\text { R-square } \\
\mathrm{N}\end{array}$ & 15,237 & $\begin{array}{l}0.362 \\
6,202\end{array}$ & 15,237 \\
\hline
\end{tabular}


Table 7: Loan intensity propensity score Probit estimation. The propensity of falling into a high loan intensity category is determined through Probit estimation of the following model: LOAN_INTENSITY_CATEGORY = LDIV,

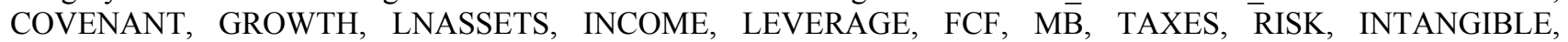
PROB_KMV, DEBT_DUM, INSIDER, INSIDER_SQ, INSTHLD, IND_LOAN_INTENSITY, NO_LEAD, industry dummies, fiscal year dummies $+e$. LOAN_INTENSITY_CATEGORY is a $1 / 0$ dummy formed as follows: observations are ranked based on LOAN_INTENSITY and observations are categorized as belonging in the high or low loan intensity category based on their relative rank. Observations are characterized as high or low loan intensity using the median. Significance levels are indicated by $* * *$ and $* * *$ that represent $10 \%, 5 \%$ and $1 \%$ level, respectively.

\begin{tabular}{lc}
\hline & Loan intensity category propensity \\
LDIV & 0.5412 \\
& $(0.5133)$ \\
COVENANT & $0.5865^{* * *}$ \\
& $(0.0274)$ \\
GROWTH & $0.0998^{* * *}$ \\
& $(0.0323)$ \\
LNASSET & $-0.3914^{* * *}$ \\
& $(0.0117)$ \\
INCOME & $0.9745^{* * *}$ \\
& $(0.0995)$ \\
LEVERAGE & $1.4681^{* * *}$ \\
& $(0.0658)$ \\
FCF & $0.2520^{* * *}$ \\
& $(0.0807)$ \\
MB & $-0.0594 * * *$ \\
& $(0.0124)$ \\
TAXES & -0.0076 \\
& $(0.0138)$ \\
RISK & $0.6334 * * *$ \\
& $(0.1954)$ \\
INTANGIBLE & $0.8325^{* * *}$ \\
PROB_KMV & $(0.0731)$ \\
DEBT_DUM & $-0.5931 * *$ \\
& $(0.1658)$ \\
INSIDER & $-0.1122^{* * *}$ \\
INSIDER^2 & $(0.0279)$ \\
INSTHLD & 0.1192 \\
& $(0.0940)$ \\
IND_LOAN_INTENSITY & -0.0524 \\
NO_LEAD & $(0.0396)$ \\
cons & $0.2643 * * *$ \\
Year dummies & $(0.0593)$ \\
Industry dummies & $5.7951^{* * *}$ \\
N & $(0.7904)$ \\
\hline
\end{tabular}


Table 8: Matched tests. Propensity scores are used to identify matches between observations characterized as high and low loan intensity. Observations are characterized as high or low loan intensity using the median. To ensure that propensity scores overlap, those high loan intensity observations whose propensity scores are outside of the range of propensity scores associated with low loan intensity observations are eliminated. Nearest neighbor matching with replacement is implemented using $k$-nearest neighbors, where $k$ is defined as 1,50 , and $100(\mathrm{NN}(1), \mathrm{NN}(50)$, and $\mathrm{NN}(100)$, respectively). For values of DIV and DIV 1/0 dummy are reported for the aggregate of the high and low loan intensity matched pairs, as well as the difference and standard error. Significance levels are indicated by $*, * *$ and $* * *$ that represent $10 \%, 5 \%$ and $1 \%$ level, respectively.

\begin{tabular}{llcc} 
& & DIV & DIV $1 / 0$ dummy \\
\hline $\mathrm{NN}(1)$ & higher loan intensity & 0.0049 & 0.3371 \\
& lower loan intensity & 0.0060 & 0.3632 \\
& Difference & $-0.0011^{* * *}$ & $-.0261^{* *}$ \\
& standard error & $(0.0004)$ & $(0.0139)$ \\
\hline $\mathrm{NN}(50)$ & higher loan intensity & 0.0049 & 0.3371 \\
& lower loan intensity & 0.0060 & 0.3644 \\
& Difference & $-0.0011^{* * *}$ & $-0.0273^{* *}$ \\
& standard error & $(0.0003)$ & $(0.0108)$ \\
\hline $\mathrm{NN}(100)$ & higher loan intensity & 0.0049 & 0.3371 \\
& lower loan intensity & 0.0059 & 0.3661 \\
& Difference & $-0.0010^{* * *}$ & $-0.0290^{* * *}$ \\
& standard error & $(0.0003)$ & $0.0106)$ \\
\hline Unmatched & higher loan intensity & 0.0049 & 0.3367 \\
& lower loan intensity & 0.0084 & 0.4759 \\
& difference & $-0.0035^{* * *}$ & $-0.1392^{* * *}$ \\
& standard error & $(0.0002)$ & $(0.0079)$ \\
\hline
\end{tabular}

